\title{
Chapter 24 \\ Waste Segregation at Source: A Strategy \\ to Reduce Waterlogging in Sylhet
}

\author{
Muntaha Rakib, Nabila Hye, and A. K. Enamul Haque
}

\section{Key Messages}

- Cities around the world have higher risk of waterlogging due to climate change

- Managing city wastes can help against the threat of waterlogging which would help to build resilience for cities in developing countries

- Increasing awareness by targeting women is the best strategy for ensuring at-home segregation to reduce the volume of solid waste

- There is a need to consider motivational approaches in campaigning that would work for women.

\subsection{Introduction}

Waste matters not only for its volume - generated due to urbanization, population pressure and economic development-but also for the fact that the rate of generation outstrips the ability of city authorities to manage and recycle (Banerjee \& Mitra, 2013; Kien, 2018). The poor waste-management process in urban areas has a harmful impact on all elements of environment and human health (Bhalla et al., 2011; Rathi, 2006). If the waste is not managed properly, then it may contaminate the groundwater aquifer (Vasanthi et al., 2008). Failure to remove waste appropriately

M. Rakib ( $\otimes)$

Department of Economics, Shahjalal University of Science and Technology, Sylhet, Bangladesh e-mail: muntaha_rakib@yahoo.com

N. Hye

Asian Center for Development, Sylhet, Bangladesh

e-mail: nabila.hye@gmail.com

\section{A. K. E. Haque}

Department of Economics, East West University, Dhaka, Bangladesh

e-mail: akehaque@gmail.com 
may lead to waterlogging and increased climate-induced urban flooding (Brand \& Spencer, 2020; Lamond et al., 2012; Pervin et al., 2020). For example, un-segregated hazardous waste may cause contamination; medical waste may cause various infections; unattended waste may create health hazards such as water-borne diseases; indiscriminate throwing of waste may cause drainage clogging and increase the intensity of floods and waterlogging (Kalina, 2020; Lamond et al., 2012). On top of this, if a city is vulnerable to climate-induced increased precipitation, it might lead to the failure of the adaptation strategy taken against urban flooding. Adaptation and resilience in urban waste management are recommended to reduce the risk of climateinduced flood and other disasters (Greenwalt et al., 2018; Kalina, 2020; Pervin et al., 2020; Phonphoton \& Pharino, 2019). Nepal et al. (2022, Chap. 21 of this volume) have shown households' willingness to pay for better waste management practices. Sharma et al., (2022, Chap. 22 of this volume) have shown possibilities of engaging community-based organizations to make people aware of climate change-related issues in urban areas. Given this, it is important to integrate the waste management process as a part of the adaptation policy.

It is widely acknowledged that public participation inclusive of all major stakeholders is a key prerequisite for efficient waste management (Buckingham et al., 2005; Adebo and Ajewole, 2012; Plavsic, 2013; Vineeshiya \& Mahees, 2016; Kien, 2018; Buckingham, 2020). The bulk of municipal solid waste (MSW) in developing countries is kitchen waste from households. Many households dispose of all waste without separating hazardous waste such as, broken glass, electric wastes, cleaning chemicals, batteries, which may be harmful to human health and the environment. Women play the primary role in waste management as part of their daily household chores. However, city managers are mostly men and women, despite being major stakeholders in generating and managing wastes in their homes, are often not consulted, resulting in inefficiency in waste management. Research findings suggest that household waste disposal is seen as a women's responsibility. Studies also find that waste segregation and disposal systems can be made efficient by mainstreaming gender within the system (Al-Khatib et al., 2009; Buckingham, 2020).

Men and women often put different precedence on solid waste management; they also probably conceptualize and produce waste differently within their household (Buckingham, 2020; Plavsic, 2013). Their allocation of time on waste management also varies, and they have different choices of waste disposal and different priorities on waste-management strategies. Moreover, men and women attach different values to the environment (Adebo and Ajewole, 2012). Research has also shown that gender mainstreaming positively affects household recycling behaviour (Babaei et al., 2015). Sustainable city waste management requires involvement and participation of women throughout the decision-making process, inclusion of gender-specific design and approaches in the information, education and awareness materials (dos Muchangos \& Vaughter, 2019).

Waste is also a resource if there is a market for recycling or reusing waste. Once it is known, women might be interested in contributing to the family income, and this could be a game-changer in waste management. 
Since the waste disposal system requires collection, segregation and disposal at a dumpsite, it is often expensive for city corporations. For example, in Kolkata, one of the largest Indian cities, the Municipal Corporation usually spends 70-75\% of its budget on collection, 25-30\% on transportation, and 5\% on disposal of municipal waste (Chattopadhyay et al., 2009). Most communities in South Asian cities do not have sanitary landfill sites, and so, there is a high risk of groundwater contamination. Improving efficiency in waste management might release financial resources to be used for developing better dumpsites.

An efficient waste-management system requires reusing, recycling and reducing the volume of waste at the source (Otitoju and Seng, 2014; Al-Khateeb et al., 2017). This reduces the burden of carrying the waste to the dumpsites. Cities in developing countries rarely segregate wastes at source. In many developing countries, however, dry waste such as paper, metal, bottles and plastic materials can be sold in the recycling markets. Composting might also allow city corporations to spend more resources on proper disposal of hazardous wastes which are detrimental to the environment. To implement any composting scheme, there is a need to engage the stakeholders who generate waste, and the first strategy is to segregate waste at source (Otitoju and Seng, 2014) into recyclable, reusable and the refuse and segregating hazardous wastes. At each step, women and men have distinct roles to play (Scheinberg et al., 1999).

There are various methods of composting including several mechanisms to initiate a process for recycling and reuse of non-biodegradable waste. The challenge is to create an innovative mechanism to ensure that communities are engaged in the process and come forward to make a change in their usual practices for disposal of waste at home. There is a need to investigate the current practice of waste management to learn about the attitude towards it and the level of awareness. This will help to design a community-engaged and efficient waste management for the city.

In this research, we worked with the Sylhet City Corporation (SCC) to find a solution to urban solid waste management by engaging with women and encouraging them to sort, separate and dispose of their daily household waste in an orderly manner to promote recycling, reuse and composting. The experience we narrate here helped the city corporation learn about a more efficient system of waste management. It also demonstrated that engaging women in the overall architecture of managing waste matters.

Section 24.2 shows the current state of city waste management, the role of women, and their attitude towards waste disposal. Section 24.3 shows how we have designed a strategy of engaging women to segregate waste at source and how it was implemented. Section 24.4 shows the results. 


\subsection{Waste-Management System in Sylhet City Corporation}

Sylhet City with a population of more than half a million has 27 Wards (smaller administrative sub-units of a municipality) which generate between 250 and 300 tonnes of solid waste a day. The Sylhet City Corporation (SCC) is responsible for managing solid waste in the city. Management of solid waste is done in two steps. The door-to-door collection or the primary collection is organized by the local Clubs who are elected by a community of 100-200 houses. Clubs are community-based voluntary organizations, not connected to the city corporation, but the councillors recognize them as an integral part of the community. Households pay a monthly fee for the daily collection of waste, and the waste collectors take the waste to a designated secondary collection centre. The city dump trucks carry the household waste from the secondary collection centre to the dumpsite. This is shown in Fig. 24.1. The dumpsite is located on the outskirts of the city from where rag-pickers collect recyclable or reusable objects. While the process is very similar in other cities in Bangladesh, the difference is that this in Sylhet the collection is organized by local clubs, whereas non-government organizations (NGOs) or civil society organizations (CSOs) manage the door-to-door collection system in other cities.

\subsubsection{Role of the Clubs}

Homeowners in a lane or several by lanes form a local voluntary association by organizing a committee for two years. The Club provides a manually operated threewheeler rickshaw van and appoints the waste-collector. Households do not perform any segregation of wastes. However, metal, plastic, glass and paper wastes are bought and sold in the market through feriwala (street vendors) who come to the locality to buy these disposable wastes often on a weekly basis. Waste collectors often segregate

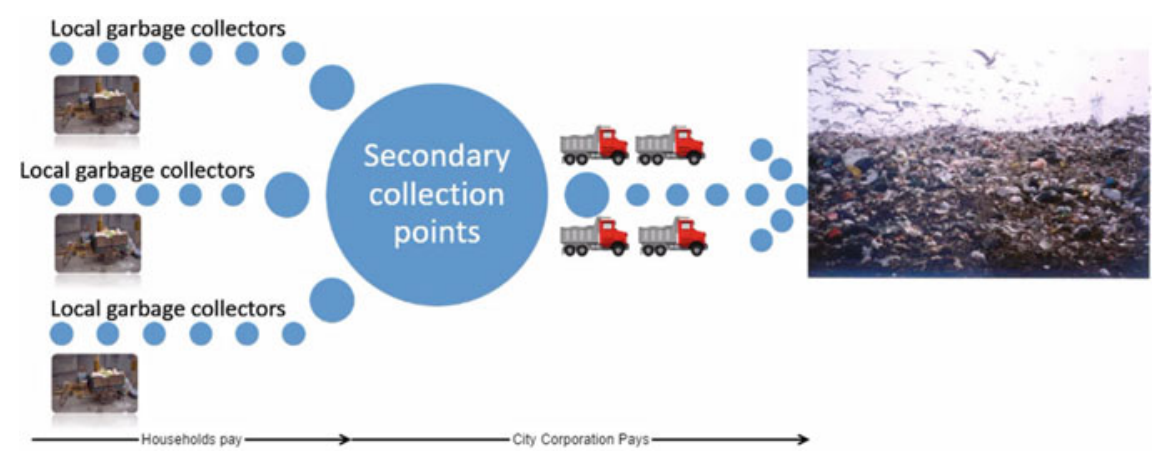

Fig. 24.1 Garbage management system in Sylhet. Source Author's conceptualisation 
the recyclable items from the wastes and sell this to the feriwala while transporting it to the secondary collection point. In many cases, the waste collector takes the waste to a nearby open place beside a canal/drain, takes out the valuables, and then throws the rest into the canal causing a long-term problem for the municipality. The canals get filled up and the clogged drains cause waterlogging during the rainy season.

Estimates show that because of waste mismanagement and improper dumping, and the depth of the canals decreases by between 10 and $20 \mathrm{~cm}$ every year. This reduces the drainage flow and during heavy rains nearly $22 \%$ of the city area is flooded causing significant damage to properties and assets (Pervin et al., 2020). Clearly, providing un-segregated garbage to the waste collector created the problem as the valuables were the incentive for the collector to deviate from their daily activities. Considering this, researchers assumed that the risk of flooding would greatly reduce if households segregate at source.

\subsubsection{A Women-Centric Approach}

Significant improvement towards reducing the waterlogging in the city is possible if the current system of waste management in the Sylhet City Corporationwhich follows the sequential course of production, collection and segregation and disposal - can be changed to production and segregation followed by collection and disposal. To do so, the role of women or a women-centric approach to waste management needs to be recognized and institutionalized. It is like shuffling the second card from the middle to the front of the deck as shown in Fig. 24.2 implying that the production points (household) also become the segregation points and are connected to the recycling markets, while the collectors are involved in composting the organic wastes.

The general solid waste-management system of Sylhet city is illustrated in A of Fig. 24.2, and the proposed alternative system is shown in B of Fig. 24.2. The

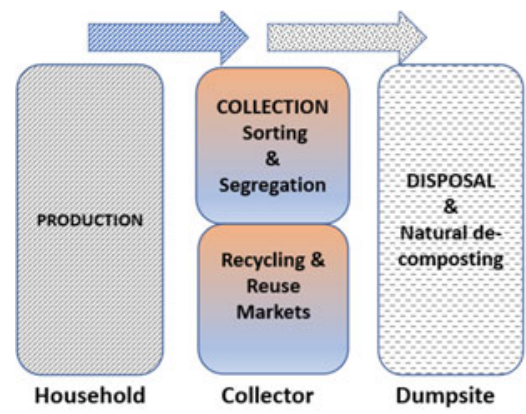

A EXISTING DISPOSAL SYSTEM

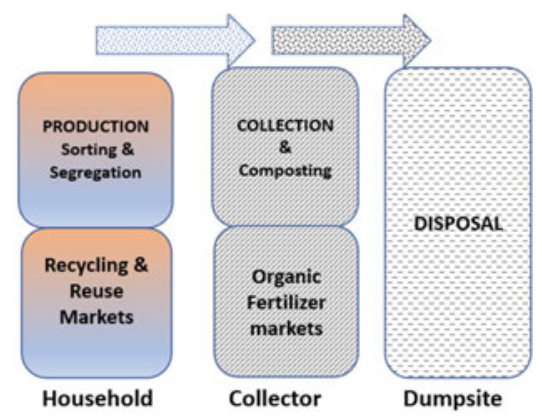

B ALTERNATIVE DISPOSAL SYSTEM

Fig. 24.2 Alternative waste-management systems. Source Author's conceptualisation 
process, if implemented properly, connects the production and collection stages of household wastes in the city with the recycling and the organic fertilizer markets. It adds value and significantly reduces transportation needs for solid wastes to the dumpsites. The key for success in such transformation is to make the production point at the household into the sorting and segregation point as well.

\subsection{Research Design}

The research was organized into two phases. Phase I consisted of understanding the current state of waste management in the city including information on current practice and volume of waste generated at the household level. Phase II involved designing several awareness campaigns to influence women to segregate waste before disposal.

While planning solid waste management for cities, the average daily waste per person per day is assumed to be between 0.32 and $0.48 \mathrm{~kg}$ (Alamgir \& Ahsan, 2007). This was verified using physical measurement of wastes generated per household per day. A small survey of 150 households was conducted for 21 days to measure (a) the composition and (b) volume of daily waste. It shows that daily waste is around $2.24 \mathrm{~kg}$ per day per household in traditional homes (one-storey buildings) which is around $0.45 \mathrm{~kg}$ per person per day. For multi-storied houses (between 2 and 6 floors), it is around $0.57 \mathrm{~kg}$. However, the result of our study was surprising for the high-rise buildings (above 6 floors) where we observed that per day an apartment generates nearly $4.9 \mathrm{~kg}$ of solid waste which is equivalent to $0.98 \mathrm{~kg}$ per person per day, nearly double the estimate. Figure 24.3 shows the distribution of waste by different types of houses.

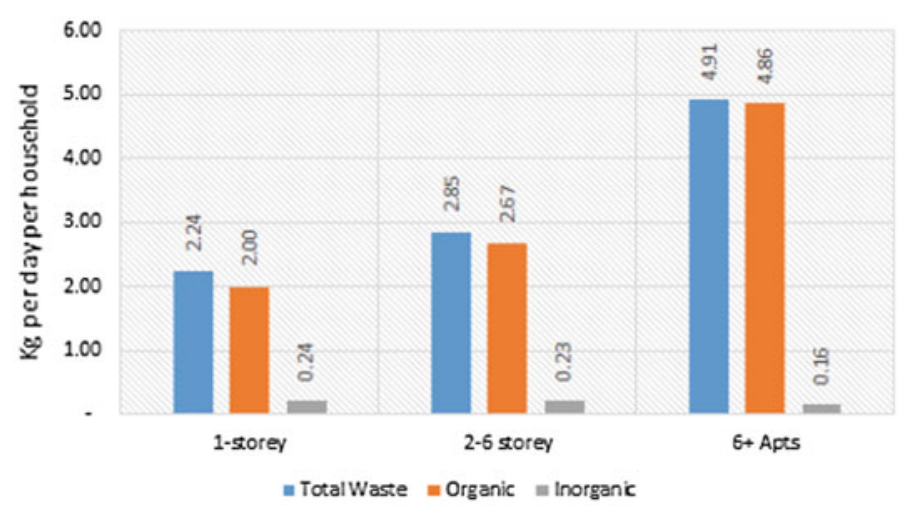

Fig. 24.3 Daily waste per household per day in Sylhet. Source Asian Center for Development Survey 2017 
The survey, therefore, provides evidence on the volume of solid waste generated daily in the city and shows that the volume is going to rise rapidly as many of the newly constructed houses are high-rise apartments. As such, it also illustrates the fact that managing solid waste in urban areas will be an important strategy in developing countries where the disposal is haphazard and public littering is common leading to clogging of the drainage system and increasing the risk of disasters during any climate-induced event.

The waste from these households was screened and weighed in two parts-(a) compostable and (b) non-compostable. It was found that nearly $92 \%$ of the waste is compostable and is mostly organic kitchen waste. As such, the research team decided to study the following strategies for in-house waste management.

- How to promote the idea of the ready market for recyclable waste.

- How to engage household members, especially women to separate kitchen waste which can be composted.

- How to provide community awareness particularly to clubs about segregation and composting including the fact that local composting is a much better option than to transport the solid waste to the dumpsite which is costly and has been ineffective so far.

\subsection{The Awareness Programme}

To design an effective awareness programme involving women, the research team decided to survey households to understand their current waste disposal behaviour in 2017 and in 2018. Three city wards were selected for the door-to-door campaign on solid waste management. Based on the baseline survey, each household was given two doses of awareness using a door-to-door campaign. The awareness programme is divided into three steps and is presented in Fig. 24.4.

In part I, workshops and seminars with city councillors and club representatives of all 27 wards in the SCC were arranged. The workshop was on the benefits of improved solid waste management to build resilience against flash floods and waterlogging.

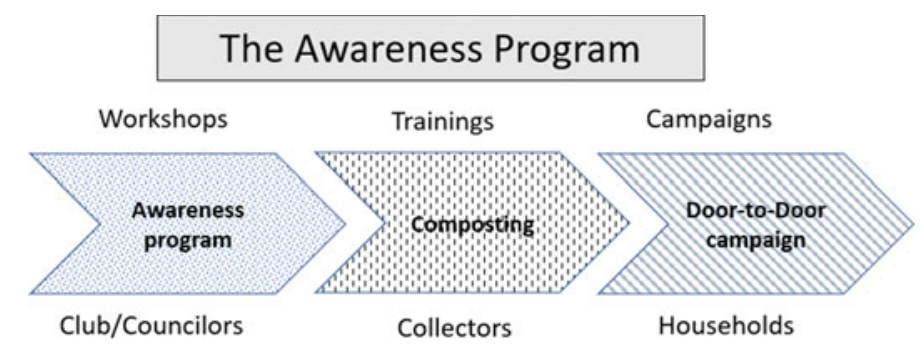

Fig. 24.4 The flowchart of the awareness programme. Source Author's conceptualization 
In part II, the waste collectors in the three selected wards were trained on composting the waste and on the benefits to the city and their own health. They were trained on how to make compost out of kitchen waste after segregation. Composts produced from the waste were for them to sell in the market as organic fertilizer.

In part III, a door-to-door campaign was conducted for 14 days, in two phases of 7 days each in three blocks of the three wards to motivate women in the house to separate their kitchen waste. During the campaign, volunteers went to every house and explained the motivation for segregation to the household heads and the most prominent women in the house, distributed campaign materials and also showed a small video on diseases caused by mosquitoes due to waterlogging and clogged drainage systems (campaign materials are illustrated in Picture 2). Figure 24.5 shows a few photos from workshops, training and a door-to-door campaign targeted at women.

Figure 24.6a shows health benefits of separating kitchen waste for the city and its potential impact on reducing waterlogging. It also shows two ways of separating household wastes: degradable and non-degradable, and finally gives a pictorial illustration of making composts to motivate the household to separate kitchen waste. Figure $24.6 \mathrm{~b}$ gives a list of kitchen waste materials which can be easily composted if separated at source. It also explains the benefits of using composts as a substitute for chemical fertilizer.

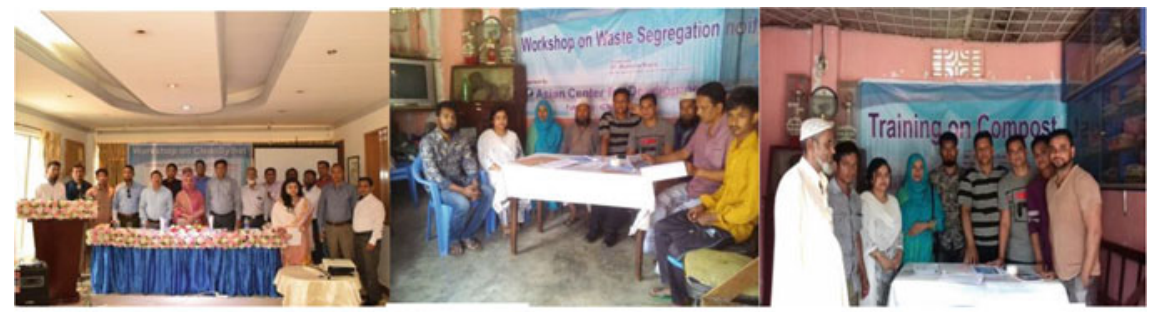

(a)

(b)

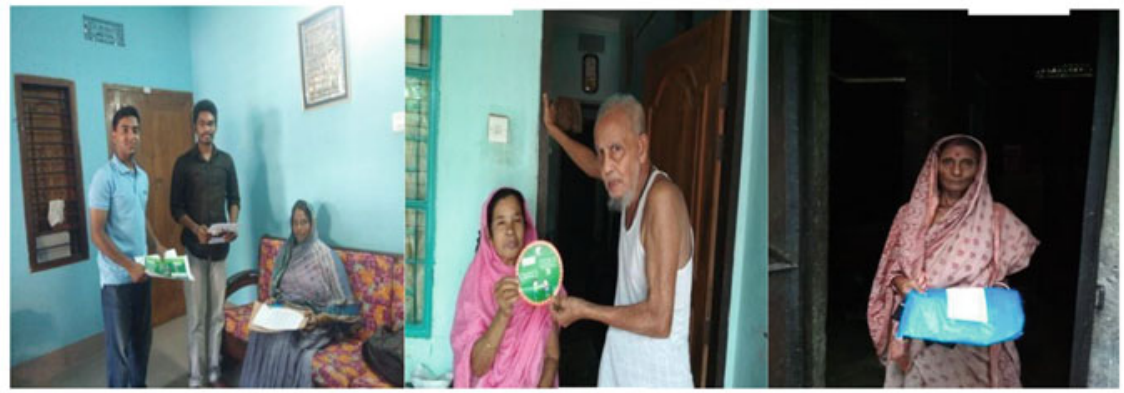

(c)

Fig. 24.5 a Various workshops and seminars with city councillors and clubs. b Training on compost to garbage collectors. c Door-to-door awareness campaign to women. Photo credits The Asian Center for Development Research Team 


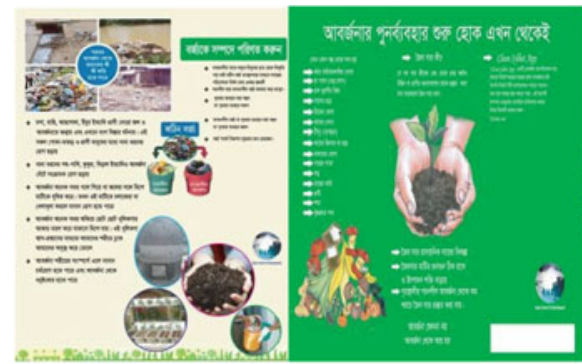

(a)

(b)

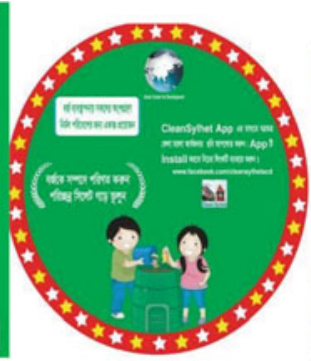

(c)

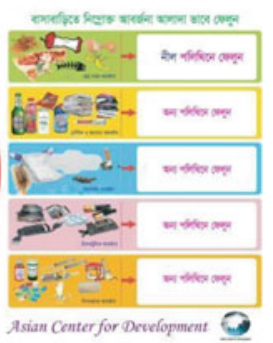

(d)

Fig. 24.6 Awareness materials. Photo credit Posters produced by the authors for the Asian Center for Development

Furthermore, it also gives a link to a mobile app (produced as part of the campaign) to report littering in the community for the City Corporation to monitor and remove. Figure $24.6 \mathrm{c}$ is a sticker distributed to every house for them to stick on their doors to motivate other members in the house to participate in segregation tasks including the link to the app to report littering in the community and to register "Clean Sylhet" campaign in their mind. Figure $24.6 \mathrm{~d}$ is a sticker for kitchen doors to define segregation of wastes for them. This is to ensure that every member of the house who is in the kitchen remembers how to dispose of their wastes separately. In addition, the volunteers showed a short video on how people are separating household waste in other countries to members present in the house at the time of their visits.

\subsubsection{Campaign Game Plan}

The campaign designed to promote separation of household wastes at home was targetted at the women of the household and based on four motivational factors: (i) social persuasion; (ii) moral persuasion; (iii) economic incentives and (iv) social recognition.

\subsubsection{Mechanism of Social Persuasion}

In order to persuade the households to segregate their wastes, we not only sensitized them to separate their kitchen waste, sanitary/medical waste and hazardous waste but also distributed blue coloured W-shaped poly bags of a pack of 60 for two months (each bag was of $12^{\prime \prime} \times 9^{\prime \prime}$ in. in dimension with an average weight carrying capacity of $5 \mathrm{~kg}$ ). A set of households were also given black-coloured poly bags for separating hazardous wastes (broken glass, battery, electrical and electronic gadget and light bulb). 
Since Sylhet is a densely populated urban area, household-based composting seemed to be unfeasible, so we provided community-based compost bins for segregated kitchen wastes and involved local garbage collectors and the club to organize composting.

\subsubsection{Mechanism for Moral Persuasion}

To motivate households to properly dispose their wastes and to separate kitchen wastes, we (a) developed the "Clean Sylhet" mobile app which can be used by any person in the community to report littering in the community to the City Council; (b) showed them a motivational video on how other communities around the world participate in such activities and separate their wastes and how it benefits the community in terms of reduced health hazards.

\subsubsection{Mechanism for Economic Incentives}

The research team introduced two mechanisms to develop economic incentives for households and for the garbage collectors. First, by selling the non-degradable wastes in the waste-recycling market households can earn extra income. Garbage collectors could also earn additional income by selling the compost. Our experiment shows that each waste bin can produce nearly $51 \mathrm{~kg}$ of good quality compost a month providing the garbage collector with an earning of nearly 15 USD or 1275 taka a month.

\subsubsection{Mechanism for Social Recognition}

The campaign introduced a process of social recognition by announcing Green Award for different stakeholders in the community. The categories are: "Green Home Award" for three best households, "Green Club Award" for three best clubs and "Clean Sylhet Award" for three waste collectors who actively participated in the activities to make the city clean. The award winners were nominated based on specific criteria that they had to fulfil. 


\subsection{Lessons Learned}

\subsubsection{Did the Women-Centric Approach Work?}

Our objectives were to understand whether our campaign was effective; whether households became socially responsible and separated their hazardous wastes; and whether they were motivated by the incentives and increased their participation to sell their waste.

Based on the four mechanisms of the campaign to motivate the women in the households, we find the following results (shown in Table 24.1). Comparing the before campaign and immediately after campaign scenarios among the households, Table 24.1 shows that our women-centric approach to pursue households to separate their wastes yielded positive outcomes. First, there has been a $484 \%$ increase among participating households in separating kitchen wastes. 60 days long daily monitoring of garbage collection data shows that $72.8 \%$ of the households participated regularly and separated their kitchen waste for community-based composting and $6.9 \%$ participated in home-based composting. Second, separation of hazardous waste increased by $33 \%$ and that of sanitary wastes by $51 \%$. There was no direct benefit to the households for doing this, but it was one of the objectives of the campaign and also used as a criterion for the Green Award declared by the City Mayor. Third, the baseline survey revealed that nearly $59 \%$ households used to sell their paper waste, $57 \%$ sell their plastic waste, $62 \%$ separate and sell their glass waste, $38 \%$ sell their metal waste and $58 \%$ sell their polybag waste. However, they do so over a long period of

Table 24.1 Waste segregation, reusing, recycling and composting by types of waste

\begin{tabular}{l|l|l|l|l}
\hline $\begin{array}{l}\text { Household activities to } \\
\text { manage waste }\end{array}$ & $\begin{array}{l}\text { Before } \\
\text { campaign }\end{array}$ & After campaign & $\begin{array}{l}\text { Percentage } \\
\text { change (\%) }\end{array}$ & $\begin{array}{l}\text { Level of } \\
\text { significance }\end{array}$ \\
\hline $\begin{array}{l}\text { Separate kitchen waste } \\
\text { for composting }\end{array}$ & 12.45 & 72.8 & 484 & $* * *$ \\
\hline $\begin{array}{l}\text { Dispose sanitary waste } \\
\text { separately }\end{array}$ & 30.71 & 46.32 & 51 & $* * *$ \\
\hline $\begin{array}{l}\text { Separate Hazardous } \\
\text { waste }\end{array}$ & 64.32 & 85.71 & 33 & $* * *$ \\
\hline $\begin{array}{l}\text { Reuse plastic/shopping } \\
\text { bag }\end{array}$ & 85.06 & 92.21 & 8 & $* *$ \\
\hline Sell waste & 45 & 47 & 4 & \\
\hline Compost in compound & 6.22 & 6.93 & 231 & \\
\hline Sample size (n) & 241 & & & \\
\hline
\end{tabular}

Source Field survey 2017 and 2018

Note $*$ indicates the change is statistically significant at $10 \%, * *$ means $5 \%$ and $* * *$ means $1 \%$. The sample sizes before and after campaigns are different because, within the span of 2 months during our campaign, 10 households left the locality and moved outside. Numbers indicate per cent of households 
time. In our survey, we further asked whether they sold their recyclable wastes in the past two months before and after the campaign. Table 24.1 shows that during the past two months before and after the campaign there was no significant change in their behaviour implying that economic incentives did not change their behaviour significantly. In terms of home composting, the increase was also not significant.

\subsubsection{Was There Any Change in the In-House Participation in Garbage Disposal?}

All members of the household were present at the time of the campaign by our volunteers. Our base-line survey results show that it is mostly women in the house who participate in the garbage management activities. Table 24.2 shows the role of women within the household in terms of waste management, disposal and compost making before and after the campaign. It shows that as a result of our campaign in the house, it was women who became more motivated than men, and so, there has been a $21 \%$ rise in the role of women to manage their waste properly. Women also took more interest in the disposal activities, and there has been a $14 \%$ rise in waste disposal activities by women. These are all statistically significant. However, as previously mentioned at-home, composting did not increase significantly.

Table 24.2 Activities of women in waste management

\begin{tabular}{l|l|l|l|l}
\hline Activities of women & $\begin{array}{l}\text { Before the } \\
\text { campaign }\end{array}$ & $\begin{array}{l}\text { After the } \\
\text { campaign }\end{array}$ & $\begin{array}{l}\text { Percentage } \\
\text { change (\%) }\end{array}$ & $\begin{array}{l}\text { Level of } \\
\text { significance }\end{array}$ \\
\hline $\begin{array}{l}\text { Waste management in } \\
\text { the house by women }\end{array}$ & 62.76 & 76.19 & 21 & $* * *$ \\
\hline $\begin{array}{l}\text { Waste disposal in the } \\
\text { house by women }\end{array}$ & 65.56 & 74.89 & 14 & $* *$ \\
\hline $\begin{array}{l}\text { Waste to compost in } \\
\text { the compound by } \\
\text { women }\end{array}$ & 46.67 & 50 & 7 & \\
\hline Sample size (n) & 241 & 231 & & \\
\hline
\end{tabular}

Source Field survey 2017 and 2018

Note *indicates the change is statistically significant at $10 \%, * *$ means $5 \%$ and ***means $1 \%$. The sample size between before and after campaigns is different because within the span of 2 months during our campaign, 10 households left the locality and moved outside. Numbers indicate per cent of households 


\subsection{Conclusions}

Cities around the world have higher risk of waterlogging due to climate change. Previous research has shown that without developing a proper waste-management policy, investment in drainage infrastructure is likely to fail. There is a need to develop a mechanism to reduce the risk of clogging of the city drainage system. This research was a follow-up to find strategies to increase household-level participation. Based on previous surveys, it was also observed that women are at the centre of waste management in a typical urban house in Bangladesh. Consequently, this research has used motivational approaches to motivate households to participate and dispose of their garbage in an orderly fashion. The team ran a campaign in selected localities for 14 days, two periods of 7 days each, in order to (a) pursue households to separate their kitchen wastes for community level composting, (b) make the city clean and smart given the climate risks.

Four motivational approaches were used: (a) social persuasion, (b) moral persuasion, (c) economic incentives and d) social recognition to motivate the city dwellers to separate their kitchen wastes. All household members present at the time in the household were motivated to participate in the activities, but the campaign also ensured that the main women in the house were present at the time of the campaign. Our results show that social and moral persuasion and the strategy of social recognition worked well, and it is the women members in the house who were more motivated by such campaigns. Women are not particularly attracted by the economic incentives shown in our campaign, maybe because the economic benefit is small compared to the income of the household. In terms of participation in managing household wastes, the campaign resulted in greater motivation in women to manage their wastes responsibly. Finally, in terms of social recognition, it was also evident that all the prize winners were women.

The study draws several conclusions. First, providing awareness by targeting women in the house to manage wastes and to at-home segregation is the best strategy for cities in developing countries to manage city wastes which would help build resilience against the threat of waterlogging. Second, while developing campaigns there is a need to consider motivational approaches that would work for womenthese are-motivation to build a better society, motivation to create a safer locality and recognition of their work.

Finally, there is a social dividend to develop such resilience. Nearly, half of the global population lives in cities. Cities in developing countries are generally more vulnerable to climate change, and thus have greater adaptation needs. The study reveals that encouraging women to manage solid waste using community-based composting not only helps the cities to reduce their risks it also reduces the burden on cities to dispose of a huge volume of municipal solid wastes to garbage disposal sites. It makes the cities climate resilient and promotes the concept of sustainable and resilient cities which is one of the sustainable development goals. 
Acknowledgements Financial support is gratefully acknowledged from the International Development Research Centre (IDRC), Ottawa, Canada (Grant \#08283-001). The Research is jointly collaborated with South Asian Network for Development and Environmental Economics (SANDEE), Asian Center for Development (ACD), Institute of Water Modelling (IWM) and Sylhet City Corporation (SCC). The authors would like to acknowledge the contributions and cooperation of The City Mayor, Chief officials of SCC, Ward Councillors, Club members and all the respondents and enumerators.

\section{References}

Adebo G. M., \& Ajewole, O. C. (2012). Gender and the Urban environment: Analysis of willingness to pay for waste management disposal in Ekiti-State, Nigeria. American International Journal of Contemporary Research, 2(5).

Alamgir, M., \& Ahsan, A. (2007). Municipal solid waste and recovery potential: Bangladesh perspective. Iranian Journal of Environmental Health, Science and Engineering, 4(2), 4. ISSN: P-ISSN: 1735-1979.

Al-Khateeb, A. J., Al-Sari, M. I., Al-Khatib, I. A., \& Anayah, F. (2017). Factors affecting the sustainability of solid waste management system-The case of Palestine. Environmental Monitoring and Assessment, 189(2), 93.

Al-Khatib, I. A., Arafat, H. A., Daoud, R., \& Shwahneh, H. (2009). Enhanced solid waste management by understanding the effects of gender, income, marital status, and religious convictions on attitudes and practices related to street littering in Nablus-Palestinian territory. Waste Management, 29(1), 449-455.

Babaei, A. A., Alavi, N., Goudarzi, G., Teymouri, P., Ahmadi, K., \& Rafiee, M. (2015). Household recycling knowledge, attitudes and practices towards solid waste management. Resources, Conservation and Recycling, 102, 94-100.

Banerjee, S., \& Mitra, S. (2013). Radioactive and hospital waste management: A review. International Journal of Latest Trends in Engineering and Technology (IJLTET), 3(1), 275-282.

Bhalla, G., Kumar, A., \& Bansal, A. (2011). Assessment of groundwater pollution near municipal solid waste landfill. Asian Journal of Water, Environment and Pollution, 8(1), 41-51.

Brand, J. H., \& Spencer, K. L. (2020). Will flooding or erosion of historic landfills result in a significant release of soluble contaminants to the coastal zone? The Science of the Total Environment, 724, 138150. https://doi.org/10.1016/j.scitotenv.2020.138150

Buckingham, S. (2020). Gender and environment. Routledge.

Buckingham, S., Reeves, D., \& Batchelor, A. (2005). Wasting women: The environmental justice of including women in municipal waste management. Local Environment, 10(4), 427-444. https:// doi.org/10.1080/13549830500160974

Chattopadhyay, S., Dutta, A., \& Ray, S. (2009). Municipal solid waste management in Kolkata, India-A review. Waste Management (New York, N.Y.), 29, 1449-1458. https://doi.org/10.1016/ j.wasman.2008.08.030

dos Muchangos, L., \& Vaughter, P. (2019). Gender mainstreaming in waste education programs: A conceptual framework. Urban Science, 3(29), 1-12. https://collections.unu.edu/view/UNU:7262.

Greenwalt, J., Raasakka, N., \& Alverson, K. (2018). Chapter 12-Building urban resilience to address urbanization and climate change. In Z. Zommers \& K. Alverson (Eds.), Resilience (pp. 151-164). Elsevier. https://doi.org/10.1016/B978-0-12-811891-7.00012-8

Kalina, M. (2020). Waste management in a more unequal world: Centring inequality in our waste and climate change discourse. Local Environment, 25(8). https://www.tandfonline.com/doi/abs/ $10.1080 / 13549839.2020 .1801617$

Kien, A. H. (2018). A gender perspective of municipal solid waste generation and management in the city of Bamenda, Cameroon. Langaa Rpcig. 
Lamond, J., Bhattacharya, N., \& Bloch, R. (2012). The role of solid waste management as a response to urban flood risk in developing countries, a case study analysis (pp. 193-204). https://doi.org/ 10.2495/FRIAR120161

Nepal, M., Bharadwaj, B., Nepal, A. K, Khadayat, M. S., Pervin, I. S., Rai, R. K., \& Somanathan, E. (2022). Making urban waste management and drainage sustainable in Nepal. In A. K. E. Haque, P. Mukhopadhyay, M. Nepal, M. R. Shammin (Eds.), Climate change and community resilience: Insights from South Asia (pp. 325-338). Springer Nature.

Otitoju, T. A., \& Seng, L. (2014). Municipal solid waste management: Household waste segregation in Kuching South City, Sarawak, Malaysia. American Journal of Engineering Research, 10.

Pervin, I. A., Rahman, S. M. M., Nepal, M., Haque, A. K. E., Karim, H., \& Dhakal, G. (2020). Adapting to urban flooding: A case of two cities in South Asia. Water Policy, 22(S1), 162-188. https://doi.org/10.2166/wp.2019.174

Phonphoton, N., \& Pharino, C. (2019). A system dynamics modeling to evaluate flooding impacts on municipal solid waste management services. Waste Management, 87, 525-536. https://doi. org/10.1016/j.wasman.2019.02.036

Plavsic, S. (2013). An investigation of gender differences in pro-environmental attitudes and behaviors.

Rathi, S. (2006). Alternative approaches for better municipal solid waste management in Mumbai, India. Waste Management, 26(10), 1192-1200.

Scheinberg, A., Muller, M., \& Tasheva, E. L. (1999). Gender and waste. UWEP Working Document, 12.

Sharma, U., Brahmbhatt, B., \& Panchal, H. N. (2022). Do community-based institutions spur climate adaptation in urban informal settlements in India? In A. K. E. Haque, P. Mukhopadhyay, M. Nepal, M. R. Shammin (Eds.), Climate change and community resilience: Insights from South Asia (pp. 339-356). Springer Nature.

Vasanthi, P., Kaliappan, S., \& Srinivasaraghavan, R. (2008). Impact of poor solid waste management on ground water. Environmental Monitoring and Assessment, 143(1-3), 227-238. https://doi.org/ 10.1007/s10661-007-9971-0

Vineeshiya, M. N., \& Mahees, M. T. M. (2016). Gender perspective of community participation in solid waste management; A case of balangoda urban council, Sri Lanka.

Open Access This chapter is licensed under the terms of the Creative Commons AttributionNonCommercial-NoDerivatives 4.0 International License (http://creativecommons.org/licenses/bync-nd/4.0/), which permits any noncommercial use, sharing, distribution and reproduction in any medium or format, as long as you give appropriate credit to the original author(s) and the source, provide a link to the Creative Commons licence and indicate if you modified the licensed material. You do not have permission under this licence to share adapted material derived from this chapter or parts of it.

The images or other third party material in this chapter are included in the chapter's Creative Commons licence, unless indicated otherwise in a credit line to the material. If material is not included in the chapter's Creative Commons licence and your intended use is not permitted by statutory regulation or exceeds the permitted use, you will need to obtain permission directly from the copyright holder.

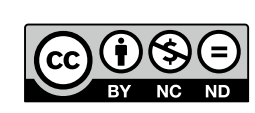

